\title{
VERNACULAR REGIONS AS A DETERMINANT FOR DEVELOPMENT OF CREATIVE TOURISM IN BOSNIA AND HERZEGOVINA
}

\author{
Snježana Musa ${ }^{1}$ \\ Željka Šiljković ${ }^{2}$ \\ Azra Čelik ${ }^{3}$
}

\begin{abstract}
Creative tourism is an escape from unvaried offer and mass cultural tourism. It is based on direct encounters between "tourists" and "locals" with exchange of authentic experiences. This fact indicates its relationship and reliance on specificity which is manifested by separation of the vernacular region. Creative tourism was recognized as a selective form of tourism twenty years ago, but in this area it has just begun.

An important role for a good plan of tourism developing in certain tourist destination, especially for the problem of seasonality, plays the valorisation of the cultural and historic heritage. Since the intangible heritage is the base of creative tourism, the customs, beliefs, games, gastronomy, embroidery, dance, crafts and other skills are the key elements of modern tourism demand.

There is no mass tourism or selective tourism offer in Bosnia and Herzegovina. Creative tourism could be developed and based on the distinctive vernacular regions. Separating the vernacular regions is an important issue which will be discussed about by the authors in this paper at the level of only recognition, by using the survey method. Based on the results, this paper will present the determinants and potentials for the development of creative tourism. Problem on the way of development is the need of recognizing that potential by the local community, making a strategic plan, but also building the awareness of local people about the potential and possibilities of valorisation of the same in terms of tourism offer. It is necessary to educate the local population for the purpose of this type of tourism.
\end{abstract}

Key words: creative tourism, intangible heritage, vernacular region $\mathrm{B} \& \mathrm{H}$, education

\section{INTRODUCTION}

Cultural tourism is considered as a form of tourism based on many fields of interest. It is represented by visiting institutions (museums, galleries, historical amenities, theaters, concert halls etc.), cultural heritage of a visited community and the lifestyle of domicile population (historical cities and neighborhoods, streets, monuments, costums, language, gastronomy). In that way tourists can be introduced to lifestyle, history, art, architecture and religion of people who live a different life than themselves. According to the dominant interest, cultural tourism can be classified into: religious, cultural, historical, urban, lifeseeking and life-participating, ethnic, educational, museum, art, manifestation, congress and so on.

Cultural tourism is being supported by the EU, European Council and Unesco through many projects, organizations, cooperations and financing. This is because cultural tourism increases the interaction between different countries and helps in understanding the term 'multiculturality'. Europe has recognized that culture is a significant resource in tourism. In

\footnotetext{
${ }^{1}$ Full professor, Department of Geography, Faculty of Science, University of Mostar, Mostar, Bosnia and Herzegovina.

${ }^{2}$ Full professor, Department of Geography, University of Zadar, Zadar, Croatia.

${ }^{3}$ MA student, Department of Geography, Faculty of Science, University of Sarajevo, Sarajevo, Bosnia and Herzegovina.
} 
support of this fact come many examples of preservation of tangible and intangible cultural heritage and projects such as 'Roads of culture' and 'European cities of culture'.

Bosnia and Herzegovina is still in its initial phase of cultural tourism development. In order to interlace culture and tourism into cultural tourism there needs to be a planned strategical development. Domicile inhabitants laso have a significant role and should develop a collective awareness about the impact and significance of culture on tourism development. Only when culture is recognized as an important element of tourism in domicile surroundings, then it can become an object of interest for tourists.

The affirmation of culture inside governmental institutions, private sectors and media is the next step towards accomplishing newpartnerships giving support, creating inovative solutions, investing in the cultural sector and promoting the importance of culture to public. For further development of cultural tourism, intersectoral connection of culture and tourism is crucial in terms of collaboration between different sectors that are interested in improving and connecting cultural institutions with the holders of tourism.

The making and presenting of a tourism product based on cultural features as well as the care for preservation and protection of the above mentioned is the final goal of cultural tourism. There are three types of cultural tourism according to world literature: formal, functional and vernacular.

A vernacular cultural region is considered to be a certain space which a certain population is connected to and identifies itself with that space. This region, as well as the other two mentioned does not have clearly defined borders. It can be formed on physionomical , economical, political or historical basis.

Although it can consist of a nodus (central point), this region type is often not as organized as a functional region. Differently from formal cultural region, there is rarely a cultural homogenity in vernacular regions.

Vernacular region is closely connected with the area a man lives in. Man and space are to inseparable categories, which interact with one another. Over time, man has adapted to space or better said, space was adapted for human needs. In this connection of given space and needs a different way of life was born. One can consider vernacular region as different areas with its all-natural resources that affected the rich and varied expression of man, both in tangible and intangible terms.

Vernacular region is a region whose existence is based on the perception of its inhabitants. It is a product of spatial perception of inhabitants and a result of collective awareness of belonging to a given area.

Land differentiation of Bosnia and herzegovina according to the character of vernacular region is made on the principal of association to a particular place acting as a 'mental image' - a region that exists in people's minds.

\section{The meaning of 'vernacular regionalization' and main characteristics}

Vernacular regionalization is a process of identifying regional units of a certain spatial identity or collective experience of belonging to a certain area. Because it contains unique physical, geographical social-geographical and cultural determimants, space is the basis for the creation, design and maintenance of spatial identity. The term 'vernacular' comes from Latin origin nad is being used since the early 17 th century meaning 'innate' or 'native'. Todays growing interest in authentic and genuine, traditions and customs may be understood as a reaction to the process of globalization and the sense of alienation. 
Spatial identity is a term that indicates awareness and the feeling of belonging to a certain area. It is a result of specific historical-geographical events, natural-geographical conditions, economic terms and other factors. All of these factors affect on the existence of a specific sense of belonging to a given area with the population. Physical identity is a mindful cathegory presented by objective reality, giving names to villages, highlighting visual symbols and cultural heritage.

\section{Characteristics}

Vernacular region is a region whose existence is based on the perception of its inhabitants. It is a product of spatial perception of inhabitants and a result of collective awareness of belonging to a given area. This is a separate space entity based on cultural artifacts and antropogenic features that are interconnected and united that much so that each region gets an individual spatial character that differs from others. This is a type of a traditional (historical-geographical region) that objectively exists as a separate and identifiable area. These regions are presnet in the minds of people even in physical terms, despite numerous administrative-teritorial and general social-cultural changes.

Some regions fit into the existing political and administrative differentiation of the country. While some lost their spatial integrity and historical-geographical boundaries by integrating into new administrative frameworks. However, changes of regional system don't necesarilly lead to the destruction of existing regional conciousness because it can still continue to exist.

The subjected type of region is very complex. It is a result of long-term development of identity combined with teritoriality. Studies of complex traditional units/systems must include a wide range of criteria and elements such as language, religion, social status, tangible culture, political-geographical events, natural environment, transportation system and other. This regional conciousness is a form of homogenic sense of collective/group conciousness that arises from a homogenity of certain areas.Elements that make up the regional conciousness are: common way of life (ie. Divided existence that grows out of mutual human contact long enough), external expression or materialization (landscapes, type of construction...).

Vernacular region is closely connected with the area a man lives in. Man and space are to inseparable categories, which interact with one another. Over time, man has adapted to space or better said, space was adapted for human needs. In this connection of given space and needs a different way of life was born. One can consider vernacular region as different areas with its all-natural resources that affected the rich and varied expression of man, both in tangible and intangible terms.

Since Nature with no Man would be Space and only Space (Kojeve 1990:358), vernacular region becomes an authentic expression of a man in a certain area. All features different from Nature that give a unique personality to man's creative expression could be called 'vernacular'.

\section{Vernacular regionalization of cultural tourism in Bosnia and Herzegovina}

Vernacular cultural region is a mental image of a region that exists in the minds of people from the outside and from the experience of the authors of this paper and the results of the thesis by A. Hanjalić under the supervision of S. Musa the principle of vernacular region classification is defined as following: 
1. Uniqueness

2. Association to homeland

3. Dominance of a certain national monument cathegory from a specific period

According to such regionalization Bosnia and Herzegovina is divided into eleven regions:

These are:

1. Podrinje - 'Region of old bridges between East and West' located in Goražde,

2. High Herzegovina - 'Region of the Olimpic games and woodcarving' located in Konjic,

3. Low Herzegovina - 'Region of Virgin of Međugorje, sun, wineyards and stone' located in Mostar

4. Tropolje - 'Region of fighters, delicious food and preserved tradition' located in Livno

5. Skopaljska land - 'Region of Otomans waqf and dedication' located in Gornji Vakuf

6. Central Bosnia - ' Medieval Bosnian kingdom' located in Travnik

7. Sarajevo - 'Capital city region' located in Sarajevo

8. Salt region - 'Region of pile dwelling and saltworks' located in Tuzla

9. Posavina - 'Region of ebony and cultural heritage' located in Brčko

10. Banjaluka -'Region of Zmijan embroidery and trapist cheese' located in Banja Luka

11. Bihać - 'Region of chestnut and old towns' located in Bihać 


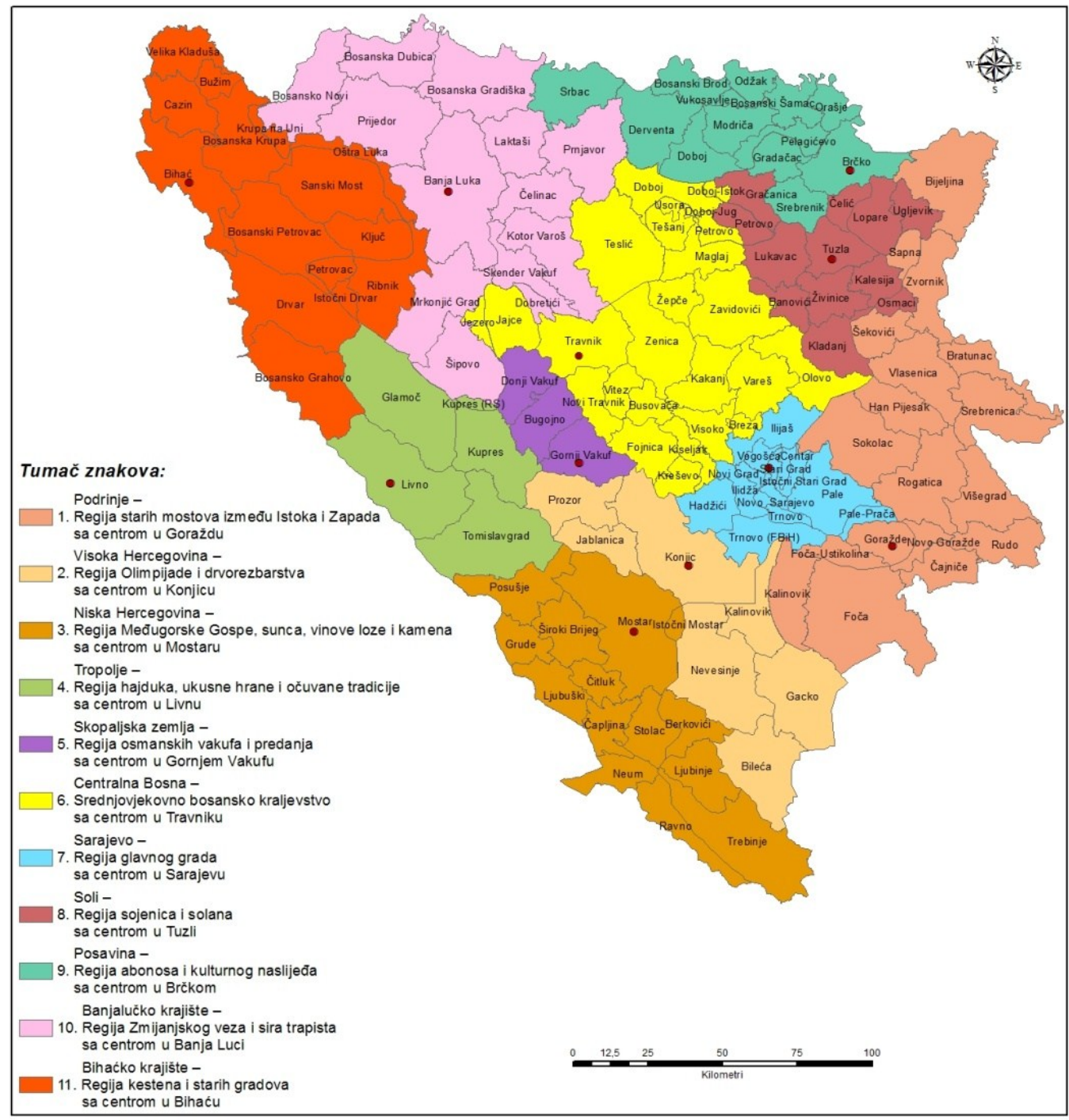

Fig. 1.Vernacular region of Bosnia and Herzegovina

Authors: S.Musa, A. Hanjalić, 2014.

The area of $\mathrm{BiH}$ is very interesting because of the particular natural-geographical conditions and specific historical-geographical circumstances which caused forming certain characteristics of the spatial identification. In the process of determining the vernacular region, historical and geographic processes and trends had great significance, which explained the emergence of vernacular region in the context of belonging to different territorial-administrative units. Due to the change of government and political currents, many cultural and ethnic changes occured, which have changed the names of geographic features. Since the names are reflecting the geographical perception of space and in meaning they carry a certain historical period, in the process of regionalization the names of the areas ( ie. Toponyms) and the originf of the terms were analized. 
Last stage of the process of defining the vernacular regions was population survey of 800 respondents. The survey covered a number of issues, among which the most important was to research what that refers to the sense of belonging to a certain vernacular region.

\section{Analysis of spatial identification on the basis of a questionnaire}

The names of vernacular region in this paper are derived from historical facts that are tied to the Middle Ages and early Ottoman period. Mentioning a particular region, a person already has some knowledge or association of space, or "mental image" of the cultural identity of its people, historical events or economic activities. All regions of Bosnia and Herzegovina have already been identified by a specific product, the traditional gastronomic specialty, historical event, person or cultural-historical inheritance. All of these elements of culture cointain history, culture and traditional way of life of this country that for centuries lived at the crossroads between East and West.

In order to complete the analysis of spatial identity and vernacular region survey was conducted on a sample of 800 respondents, whose age and education are different. Symbols of regions listed below chosen by respondents can be considered as authentic for the explored area and indicate its tradition and cultural heritage.

Podrinje is a symbol for:

1. Bridge in Višegrad, Ivo Andrić and book „Brigde over the Drina“ (23\%)

2. River Drina and rafting (11\%)

3. Spa tourism in Srebrenica - Crni Guber (8\%)

4. Grain fields in Semberija (8\%)

5. Horse farm Borike and bosnian mountain horse $(8 \%)$

6. Brigde over Žepa (6\%)

7. Bijeljinas cabage $(6 \%)$

8. Plum rakia- šljivovica (5\%)

9. Festival „Apple days“ in Goradže (4\%)

10. Fruit-growing, arables and climate $(4 \%)$

11. Train Ćiro, narrow-gauge railroad Višegrad-Sarajevo (4\%)

12. Fishing $(4 \%)$

13. Forests and canyons $(2 \%)$

14. Wool vests and socks $(1 \%)$

15. Cornel juice and apple jam (1\%)

16. Mineral springs in Srebrenica and silver mines (1\%)

17. Cheese torotan made in Janja (1\%)

18. Plums, pears and apples $(1 \%)$

19. Peasant shoe (1\%)

20. Cheese made in Čajniče, Tjentište and Sokolac (1\%) 


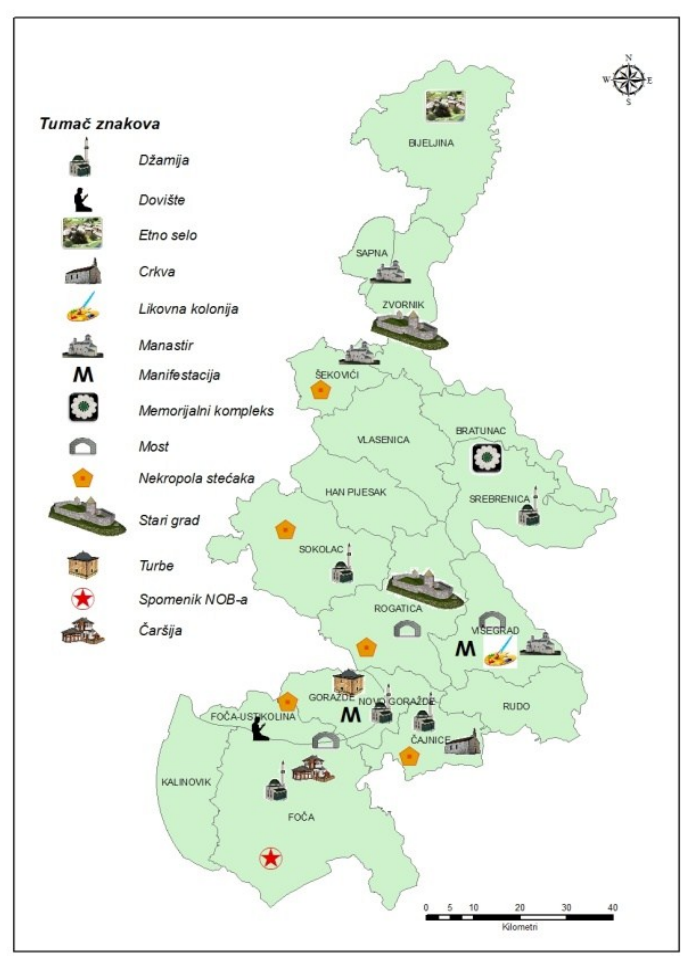

Fig.2. Podrinje

Source: Authors

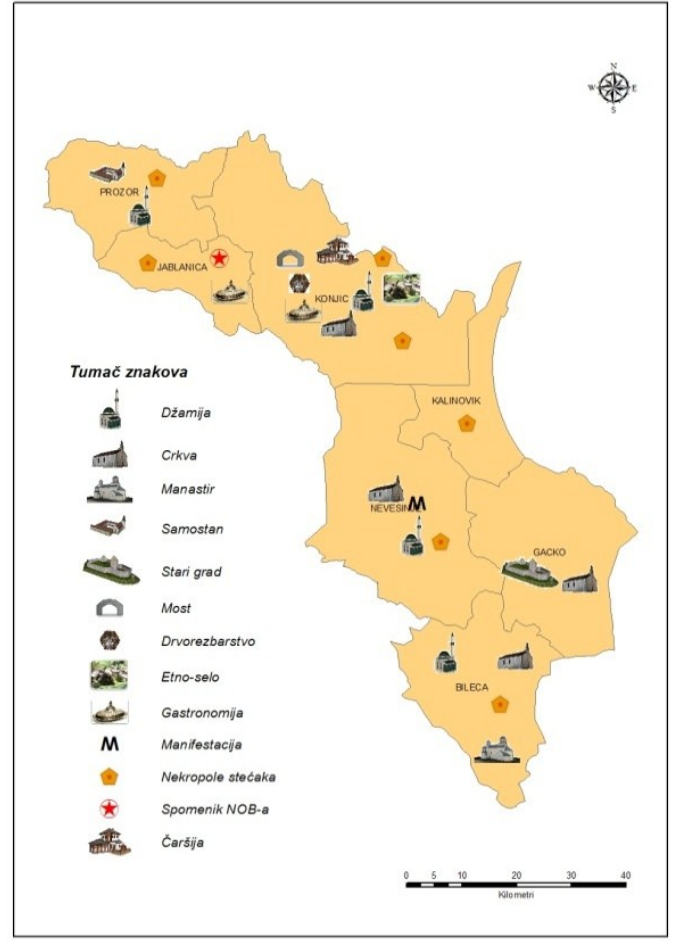

Fig. 3. High Herzegovina Source: Authors

High Herzegovina is symbol for:

1. Lamb roast $(24 \%)$

2. Rafting on Neretva ( $9 \%)$

3. Honey made in Konjic (8\%)

4. Granite in Jablanica and centenary tradition of carving (8\%)

5. Tradition of wood carving in Konjic (7\%)

6. Hercegovina prosciutto $(6 \%)$

7. Rama landscape $(6 \%)$

8. Fishing $(5 \%)$

9. Rakia (4\%)

10. Hercegovina herdsman - štukor (4\%)

11. Cheese made in Hercegovina (3\%)

12. Titos secret underground city - bunker ARK (3\%)

13. Seat events in Nevesinje (3\%)

14. Nevesinje and Aleksa Šantić (2\%)

15. Cheese presukača made in Gacko and Konjic $(2 \%)$

16. Gatačko cattle (2\%)

17. Hercegovina peasant shoe (1\%)

18. First fig in Bileća on the way to the sea $(1 \%)$

19. Traditional costume from Kalinovik (1\%)

20. Necroplis in Konjic (1\%) 
Low Hercegovina is a symbol for:

1. Old brigde in Mostar (21\%)

2. Virgin from Međugorje (14\%)

3. The colorful landscape of stone and karst $(8 \%)$

4. Specific accent $(8 \%)$

5. Indigenous wine varieties (Žilavka and Blatina), wine roats and basements (7\%)

6. Snakes and summer heat $(6 \%)$

7. Vegetables from Capljina $(5 \%)$

8. Mandarins, watermelons, figs, peaches, rosehips (pomegranate) and olives (4\%)

9. Neretva River (5\%)

10. Mostar and Trebinje cobbles (3\%)

11. Arslanagića Bridge in Trebinje (3\%)

12. Lindjo (3\%)

13. Mostar cup and "Cherry Days" (3\%)

14. Necropolis $(2 \%)$

15. Grape rakia - loza (2\%)

16. Cheese torotan Trebinje (1\%)

17. Sage and scream (1\%)

18. Stolac (1\%)

19. Herzegovinian tobacco - Ravnjak (1\%)

20. Trout at Buna in Blagaj (1\%)

21. Donkey (1\%)

Tropolje is a symbol for:

1. Livno cheese $(24 \%)$

2. Mowing on Kupres (13\%)

3. Plains and horses $(10 \%)$

4. Glamočko traditional dance $(8 \%)$

5. Potatoes from the arable karst fields (Kupres and Glamoč) (6\%)

6. Kupres traditional costume $(6 \%)$

7. Rakia $(6 \%)$

8. Livno and Duvno gang $(6 \%)$

9. Humačka board and museum of the monastery (4\%)

10. Snowy winter $(3 \%)$

11. Skiing on Kupres (3\%)

12. Wool socks (3\%)

13. Kupreško herbs (3\%)

14. Necropolis $(3 \%)$

15. Hip jam (1\%)

16. Kupreški peasant shoe (1\%) 


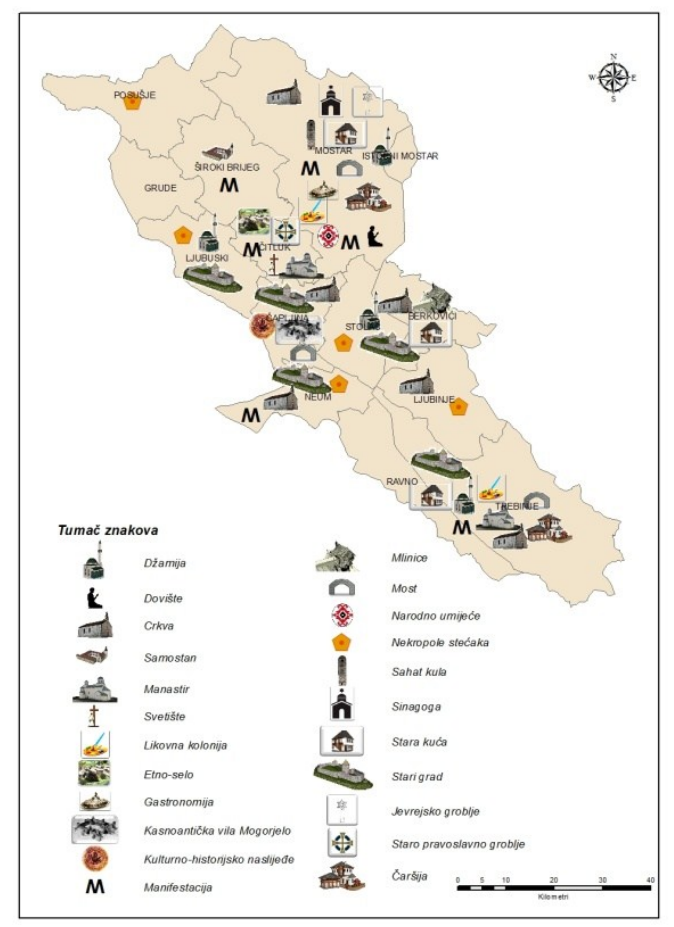

Fig. 4. Low Herzegovina Source: Authors

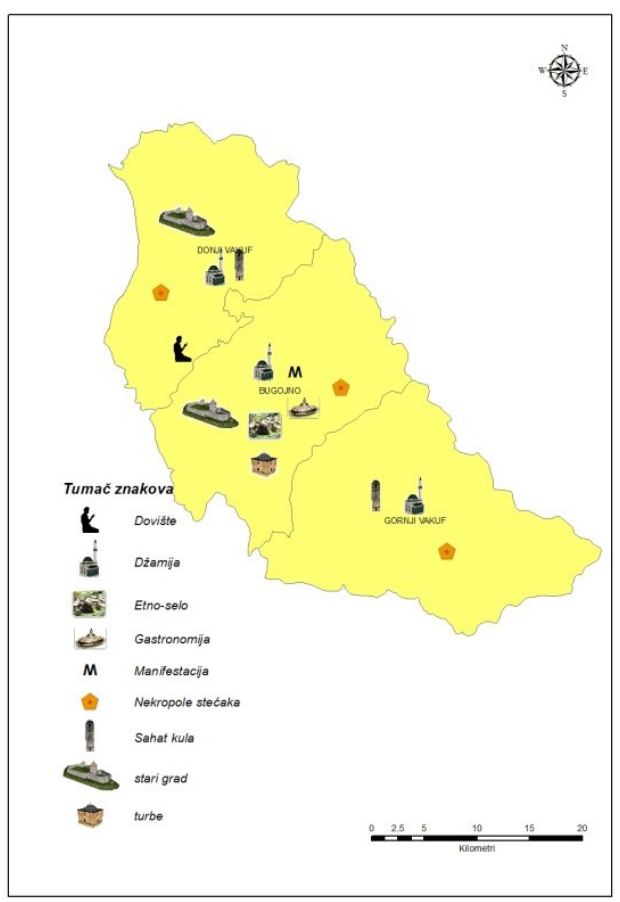

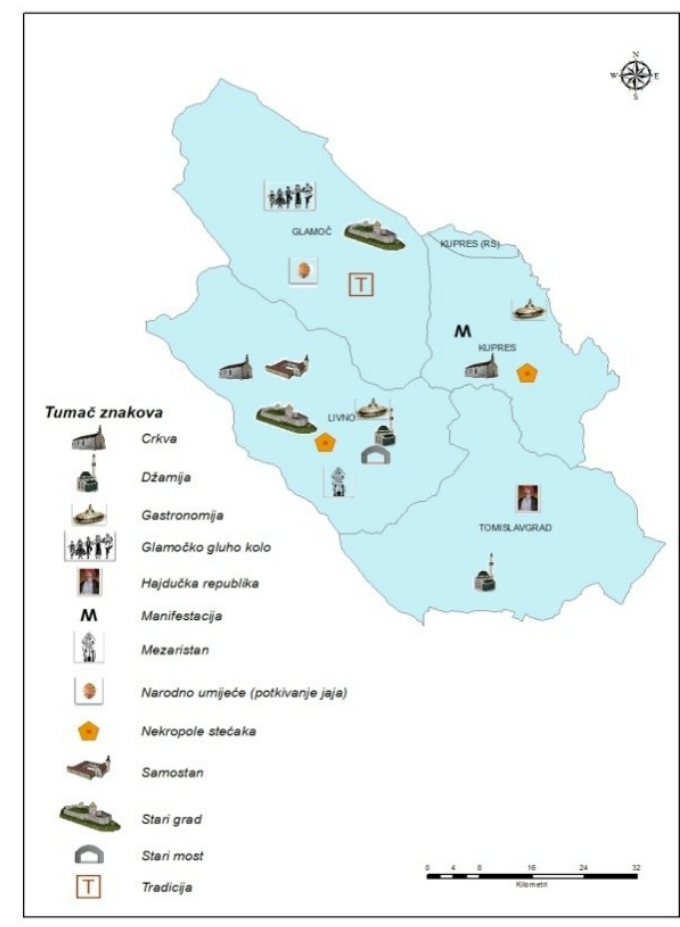

Fig. 5. Tropolje

Source: Authors

Skopaljska land is a symbol for:

1. Ajvatovica shrine (19\%)

2. Woodland and hunting (16\%)

3. Tito's villa $(16 \%)$

4. Story of the "stone wedding" (12\%)

5. "Sicanje" (tattoos) (11\%)

6. Vaqf of Mehmed Bey Stočanin (10\%)

7. Rakia (9\%)

8. Hasan Kjafi Pruščak (7\%)

9. Sauerkraut

Fig. 6. Skopaljska land Source: Authors 
Central Bosnia is a symbol for:

1. Travnikćevapis and coffee on the Blue water $(5 \%)$

2. The cultural and historical heritage, old towns and forts $(8 \%)$

3. Visočko smoked meat $(5 \%)$

4. Water mills on the Piva Lake (4\%)

5. Spa in Olovo and Fojnica (4\%)

6. Kakanj Cement (3\%)

7. The medieval kingdom and fight for the throne (3\%)

8. Zenica steelworks (8\%)

9. Medieval mines Kreševo, Vareš and Olovo (3\%)

10. Mineral water springs (4\%)

11. Zgoščanska tombstone (1\%)

12. Vlasić cheese and Travnik cream (11\%)

13. Bosnian dog Tornjak (2\%)

14. Waterfall in Jajce (7\%)

15. Tito's Museum in Jajce (5\%)

16. Potatoes from Fojnica (1\%)

17. Buckwheat with Crnoriječke plateau (4\%)

18. Monasteries and monks (3\%)

19. Thermal and mineral water springs (Tesanj, Maglaj) $(6 \%)$

20. Tanning in Visoko (6\%)

21. Bosnian Lily and Kotromanics dynasty (7\%)

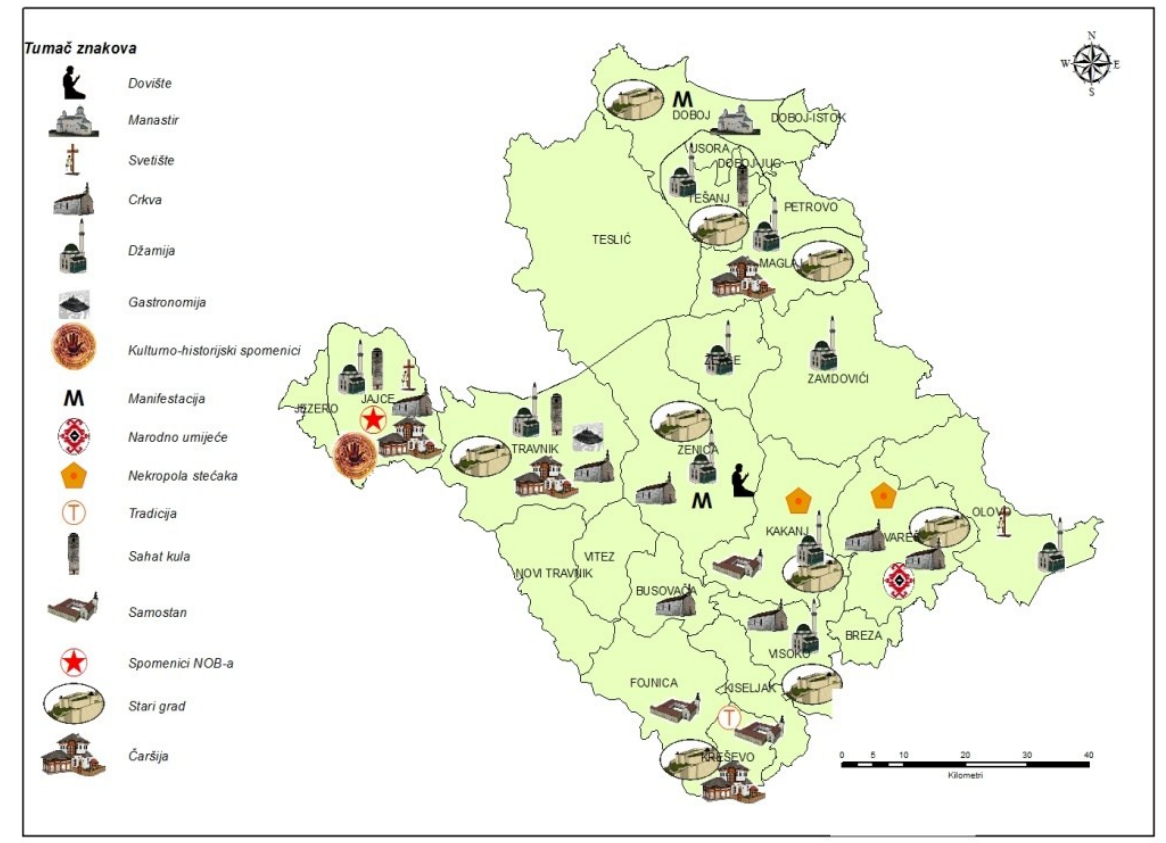

Fig. 7. Central Bosnia

Source: Authors 
Sarajevo is a symbol for:

1. Kazandžiluk street (12\%)

2. Mix of cultures and religions $(8 \%)$

3. Bosnian cuisine $(10 \%)$

4. Bosnian coffee and coffee pot Sarajevo (8\%)

5. Adhan and bells $(6 \%)$

6. Ilidža and spa (4\%)

7. Olympic mountains (7\%)

8. Bosnia Spring (4\%)

9. Pigeons $(6 \%)$

10. Flat bread (Muslims), maces and halls (the Jews), Christmas, and Easter bread (Catholics), Easter pretzels and česnica (Ortodox) (1\%)

11. Sebilj in Bascarsija (5\%)

12. The fountain near Gazi Husrev-Bey's Mosque (2\%)

13. Potatoes from Romanija (1\%)

14. Bosnian carpet $(4 \%)$

15. Haggadah $(4 \%)$

16. Ćevapi and burek (11\%)

17. Sarajevo antentat $(7 \%)$

18. Crafts

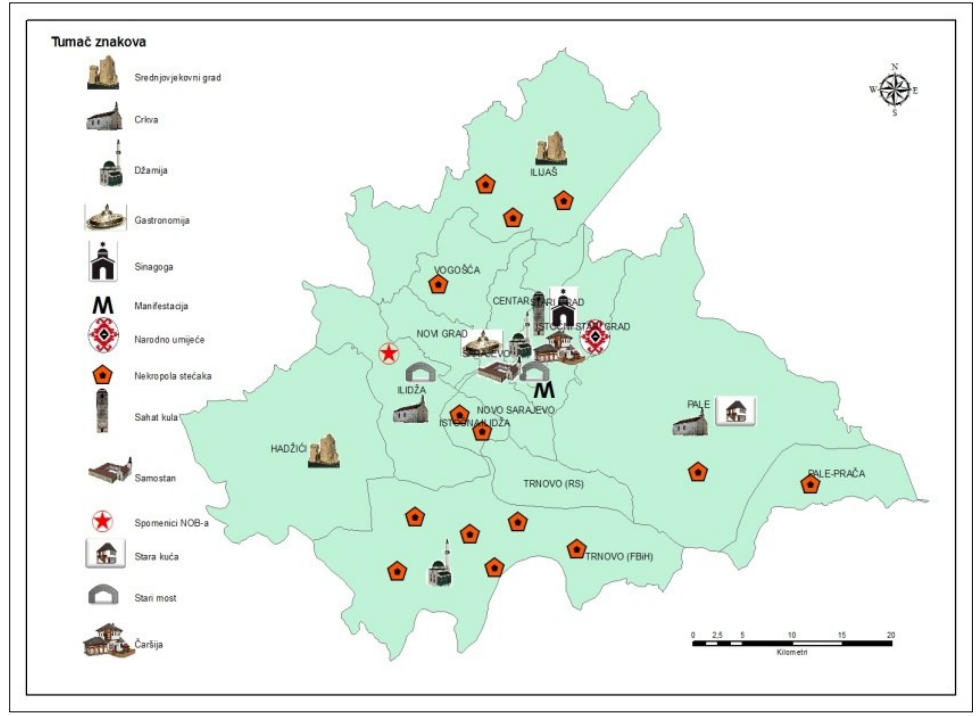

Fig. 8. Sarajevo

Source: Authors 
Salt region is a symbol for:

1. Salt production and salt works (19\%)

2. Salt Lake (13\%)

3. Meša Selimović $(9 \%)$

4. The girls' cave $(9 \%)$

5. The story of the goat $(6 \%)$

6. Mines and factories $(5 \%)$

7. Gracanica's crochet - folk art (5\%)

8. Meadow honey from the area of Majevica (5\%)

9. Apple jam (4\%)

10. Kladanj male water $(4 \%)$

11. Mine Banovići (4\%)

12. Healing waters of Tuzla and Gracanica - Karanovac (4\%)

13. Cheese (4\%)

14. Kalenderovački cheese from the Motajica mountain (3\%)

15. Kalesijan traditional dance and songs (3\%) Source: Authors

16. Gracanica cheese $(3 \%)$

Posavina is a symbol for:

1. Lowland landscape (16\%)

2. Gradačačka plum $(9 \%)$

3. Grain and corn fields (7\%)

4. Willow, poplar and posavian acacia $(7 \%)$

5. Fish specialties (7\%)

6. Oil refinery in Modriča (6\%)

7. Jam apple $(6 \%)$

8. Agriculture (5\%)

9. Plum rakia $(5 \%)$

10. The tower in Gradačac (5\%)

11. Honey (5\%)

12. Domaljevačka weaving - folk art (4\%) Source: Authors

13. Slavonski Brod Refinery (4\%)

14. Railway junction in Doboj (3\%)

15. Production of furniture, baskets and decorative objects from the cane $(3 \%)$

16. Medical Spa: Gradačačka Ilidža and Srbac (2\%)

17. Okra, sunflowers, peppers, tomatoes, eggplant and cabbage (2\%)

18. Walnuts, pears and apples, jam $(2 \%)$

19. Fields melons (watermelon) $(1 \%)$

20. Mineral water in Srebrenik (1\%) 


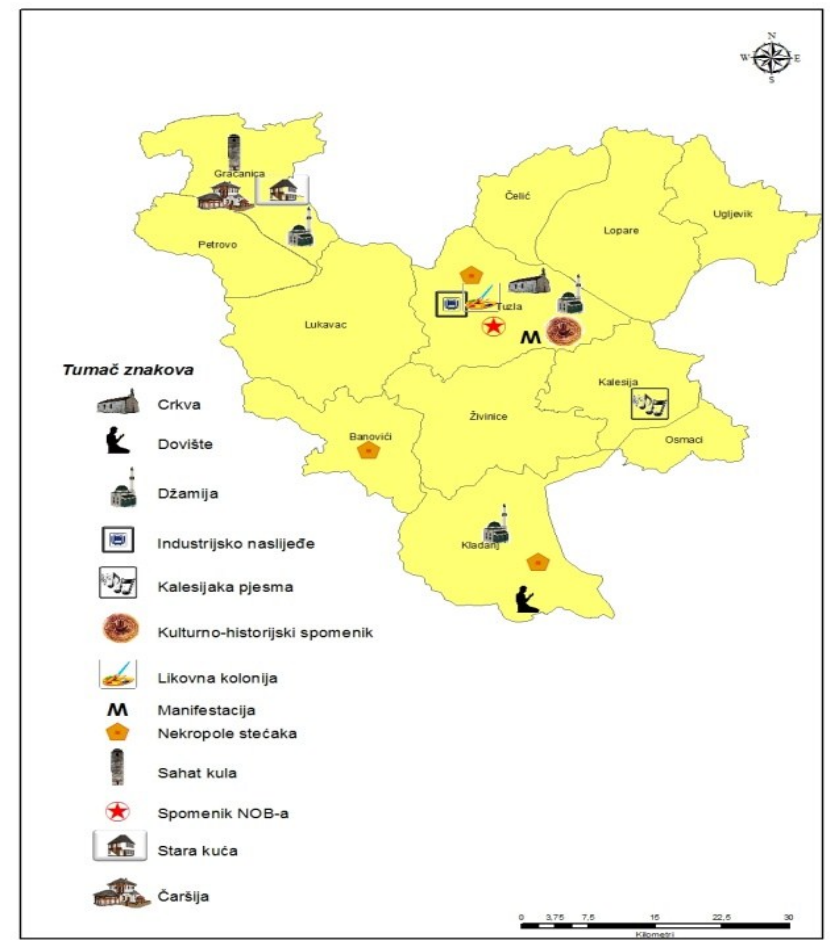

Fig. 9. Salt region

Source: Authors

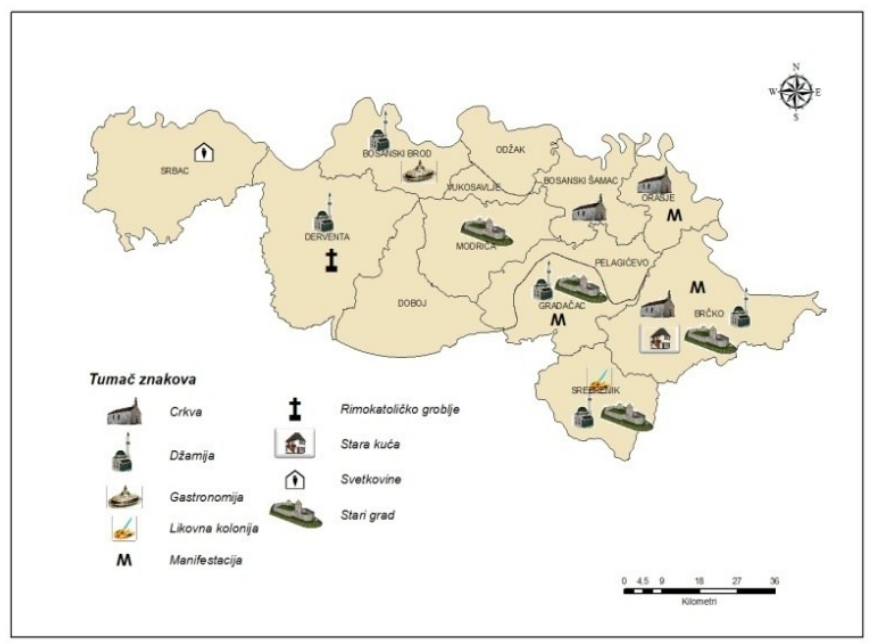

Fig. 10. Posavina

Source: Authors 
Banja Luka region is a symbol for:

1. Banja Luka Kastel (13\%)

2. Banja Luka ćevapi (13\%)

3. Vrbas $(12 \%)$

4. Beer $(10 \%)$

5. The monument on Kozara (8\%)

6. Trappist cheese $(7 \%)$

7. Chestnut honey from Kostajnica (7\%)

8. Folk dances and handicrafts $(6 \%)$

9. Anniversary ZAVNOBiH session in Mrkonjic Grad (7\%)

10. Thermal waters in the Dvorovi in Bijeljina (7\%)

11. Zmijanje $(6 \%)$

12. Prijedorska holly - native apple varieties $(4 \%)$

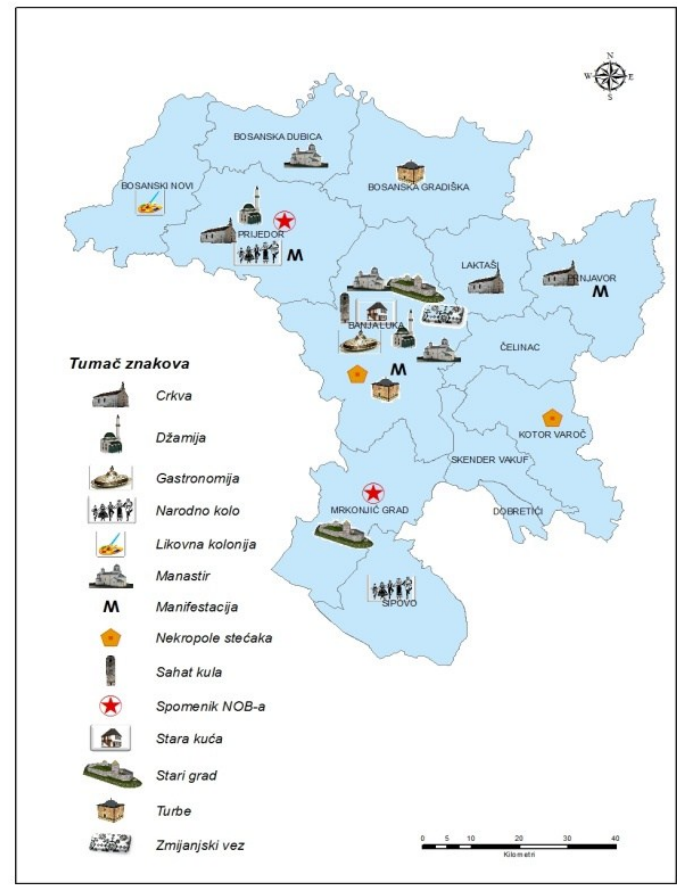

Fig. 11. Banja Luka

Source: Authors

Bihać region is a symbol for: :

1. Temperamental people $(11 \%)$

2. Hospitality $(10 \%)$

3. Old towns and towers $(9 \%)$

4. Tito's cave in Drvar $(8 \%)$

5. Una Regatta (8\%)

6. Krajiška potkriža (4\%)

7. Krajiška spicy sausage $(7 \%)$

8. Advanced industrial production (6\%)

9. River Una and Sana (6\%)

10. The characteristic accent $(5 \%)$

11. Cheese basa made in Bihac (5\%)

12. Chestnut forests $(5 \%)$

13. Grmečka bullfight (4\%)

14. Honey (4\%)

15. Gruel of wheat flour (4\%)

16. Water mills to grind corn in Martin Brod $(2 \%)$

17. Podgrmeč cream (2\%)

Fig. 12. Bihać

Source: Authors 


\section{Potential of vernacular region for creative tourism development}

Very important role on the supplier side in creative tourism have traditional crafts and art. Every place worldwide has specific tradition and areas which have unique rituals, crafts, art or anything else which is material or non-material heritage. These specifics are a key resource for the development of creative tourism and key for attracting creative tourists to the certain destination.

Complete tourist infrastructure, resources for creative tourism and other types of tourism play an important role on the supply side. The demand in tourism, not only in the creative, is often limited by poor infrastructure, which is why they decide to go to other destinations. Therefore it is very important to the overall tourism development to give special attention to the basic tourism infrastructure.

Recent, the phenomen which appeared on the tourism market is creating an creative tourism product, but still many destination don't consider creative tourism as a special type of tourism. World and regional development programs can recognize creative areas so UNESCO has a program which refers to creative cities. UNESCO has a program for creative cities. Creative clusters that "feed on diversity and change and so thrive in busy, multi-cultural urban settings that have their own local distinctiveness but are also connected to the world" (UNESCO 2006)

Because of the complexity of the creation of creative tourism products and services, several approaches are taken by DMOs, tour operators and other organizations towards creative tourism development (Ohridska-Olson, 2010):

- Destination based: creative tourism product is destination dependent. Such approach is typical tourism to creative cities, creative landscapes, corridors, or programs of tour operators that use the resources in a place already in the program of tour to the destination not specifically designed for creative tourism.

- Activity based: the creative tourism product is geographically dispersed. These are creative tourism programs based on a concrete activity.

The creative tourism business model beside demand and suplly factor containes also tangible and intangible benefits. While tangible benefits from creative tourism can be measured accordingly with the OECD (OECD 2000) definition for tourism expenditure being "the expenditure made by, or on behalf of, the visitor before, during and after the trip and which expenditure is related to that trip and which trip is undertaken outside the usual environment of the visitor", the intangible benefits coming from creative tourism are much more difficult to measure.

The tangible benefits from creative tourism can be summarised as follows (OhridskaOlson, 2010)::

- Cultural capital - increase of creative and cultural assets (tangible and intangible);

- Market expansion - growth of the geographical reach for cultural and creative industries through creative tourism;

- Innovation - increase of innovation programmes to include creative tourism for the benefits of the community;

- Cultural heritage preservation - cultural heritage is preserved mainly to serve as a renewable resource for creative tourism;

- Sustainability - one of the most important benefit from creative tourism due to it characteristics as a process of creation and renewable activity; 
- Brand visibility - local arts and crafts brands are usually not very known and valorised through tourism. Creative tourism helps brand visibility and hence, increases the brand equity for small communities;

- Job creation - in addition to the traditional tourism jobs, creative tourism create employment for artists, craftsman and other professional groups;

- Exports - in addition to the normal tourism exports, creative tourism contributes with exports of the cultural and creative industries, otherwise not related with tourism exports

The intangible benefits from creative tourism are:

- Local identity and uniqueness - the focus on unique local arts and crafts and authenticity contribute to the emphasis on local identity;

- Social capital - by increasing social values that promote social cooperation to create and operate creative tourism products and services, the social increases dramatically thanks to creative tourism;

- Cultural values preservation - instead to destroy cultural values to "please" the visitor, the local communities learnt that preserving their local cultural values help develop creative tourism;

- Local cultural diversification - in order to compete successfully on the creative tourism marketplace, which is much more sensitive to uniqueness of the tourism offerings, communities are forced to emphasize and preserve their local cultural identity, pride of place and thus provide a clear diversification of the creative tourism resources;

The financial results for the destinations are the fifth element of the creative tourism's business model. Creative tourism contributes to the local economy by generation of incomes for the local population and revenues for the municipal budgets through taxation. Creative tourism contributes to the development of certain destination whether tangible or intangible benifits.

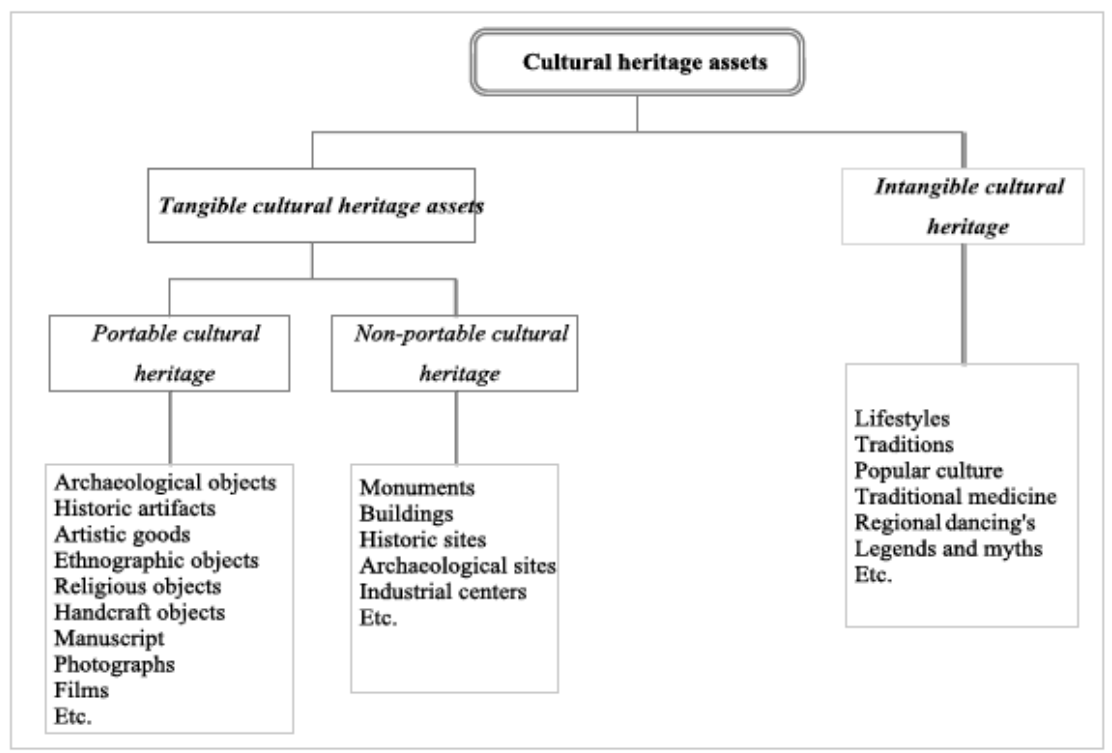

Fig. 13. Typology of cultural heritage assets

Source: Prats, 2007, Velasco Gonzales, 2009. 
Creative tourism is percived very often as part of cultural tourism and therefore he does not attach too much attention, however creative tourism stands out as a special thematic tourism within the culture. The reason for this is that the key resources of the creative tourism part of the cultural identity of a people, communities and regions. So, the creative tourism business plan is different that traditional cultural tourism business model.

Tab. 1. Creative and traditional cultural tourism models

\begin{tabular}{|l|l|}
\hline $\begin{array}{l}\text { Creative tourism business model main } \\
\text { characteristics }\end{array}$ & $\begin{array}{l}\text { Traditional Cultural Tourism business } \\
\text { model main characteristics }\end{array}$ \\
\hline $\begin{array}{l}\text { Resource Set: Based on local creative } \\
\text { capital in constant development Any } \\
\text { artistic or creative process can be resource } \\
\text { for creative tourism: knitting, crocheting, } \\
\text { traditional dance etc. }\end{array}$ & $\begin{array}{l}\text { Resource Set: based on existing cultural } \\
\text { heritage resources with predetermined } \\
\text { characteristics: buildings, events, } \\
\text { monuments etc. }\end{array}$ \\
\hline $\begin{array}{l}\text { Target markets: small groups and } \\
\text { individuals with creative interests }\end{array}$ & $\begin{array}{l}\text { Target markets: large groups and } \\
\text { individuals with general interests in culture }\end{array}$ \\
\hline $\begin{array}{l}\text { Benefits for the cultural heritage: } \\
\text { nondestructive participation, visitors } \\
\text { responsibility, creation of new cultural } \\
\text { heritage }\end{array}$ & $\begin{array}{l}\text { Benefits for the cultural heritage: mass } \\
\text { cultural tourism already represents a danger } \\
\text { for many cultural heritage sites }\end{array}$ \\
\hline $\begin{array}{l}\text { Sustainability: very high, since creative } \\
\text { tourism is based on a continuous process of } \\
\text { creation }\end{array}$ & $\begin{array}{l}\text { Sustainability: limited, since the resources } \\
\text { for cultural tourism in many cases are not } \\
\text { renewable }\end{array}$ \\
\hline
\end{tabular}

Source: Authors

So the difference between creative and cultural tourism is existing. Creative tourism business model clealry shows that any cultural tourism destination can profit from the creative tourism too. Even though the creative tourism is percieved as variety of cultural tourism, creative combines different kinds of tourism that creates a favorable basis for the development of various types of tourism so that they can connect creative and adventure tourism, cultural and creative tourism, archaeological and creative tourism, gourmet and creative tourism. Many tourist destination can improve their offer, gain more arrivals and profit with the creative tourism concept.

Regarding this charachteristic of the creative tourism in all 11 vernacular region of Bosnia and Herzegovina can be singled out several elements on which it is possible to form an offer for creative tourists, as follows:

1. Podrinje - weaving, knitting and creative workshops of new artistic techniques, festivals; 
2. High Herzegovina - wood carvings, knitting, wool spinning, embroidery, cheese production;

3. Weak Herzegovina - making cheese škripavac, cheese torotana, blacksmiths, shoemakers, tanners, goldsmiths, copper carving, wickerwork (making baskets), making peasant shoes, making Bukara (containers for wine), wine, tobacco Herzegovina;

4. Tropolje - making Livanjski cheese, Bosnian (Livno) silver wire embroidery, blacksmiths, mowing, rakia , wool products, making carpets;

5. Skopaljska region - shrine areas, rakia, blacksmiths, craft perski

6. The Central Bosnia - ćevapi, smoked meat, cheese, buckwheat, medieval stories, spas, mines, folklore dancing, bullfighting

7. Sarajevo - coppersmiths, goldsmiths, making nanulas, tanners, making souvenirs, jewelers, Ilidža, festivals, creative workshops of new art trends, folk society, traditional cuisine, Sarajevo beer,

8. Salt region - Museum of salt, the saltworks , abandoned factories, mines, cheese, kalenderovački cheese, Kalesijan folk dance and songs

9. Posavina - grain fields, fish, agriculture, honey, weaving, wickerwork, spas,

10. Banjalučko krajište - Zmijanje embroidery, Trappist cheese, Banjalučko beer, honey, making dajak boats, wool producst;

11. Bihaćko krajište -Krajiška spicy sausage, cheese basa, cream, bullfight;

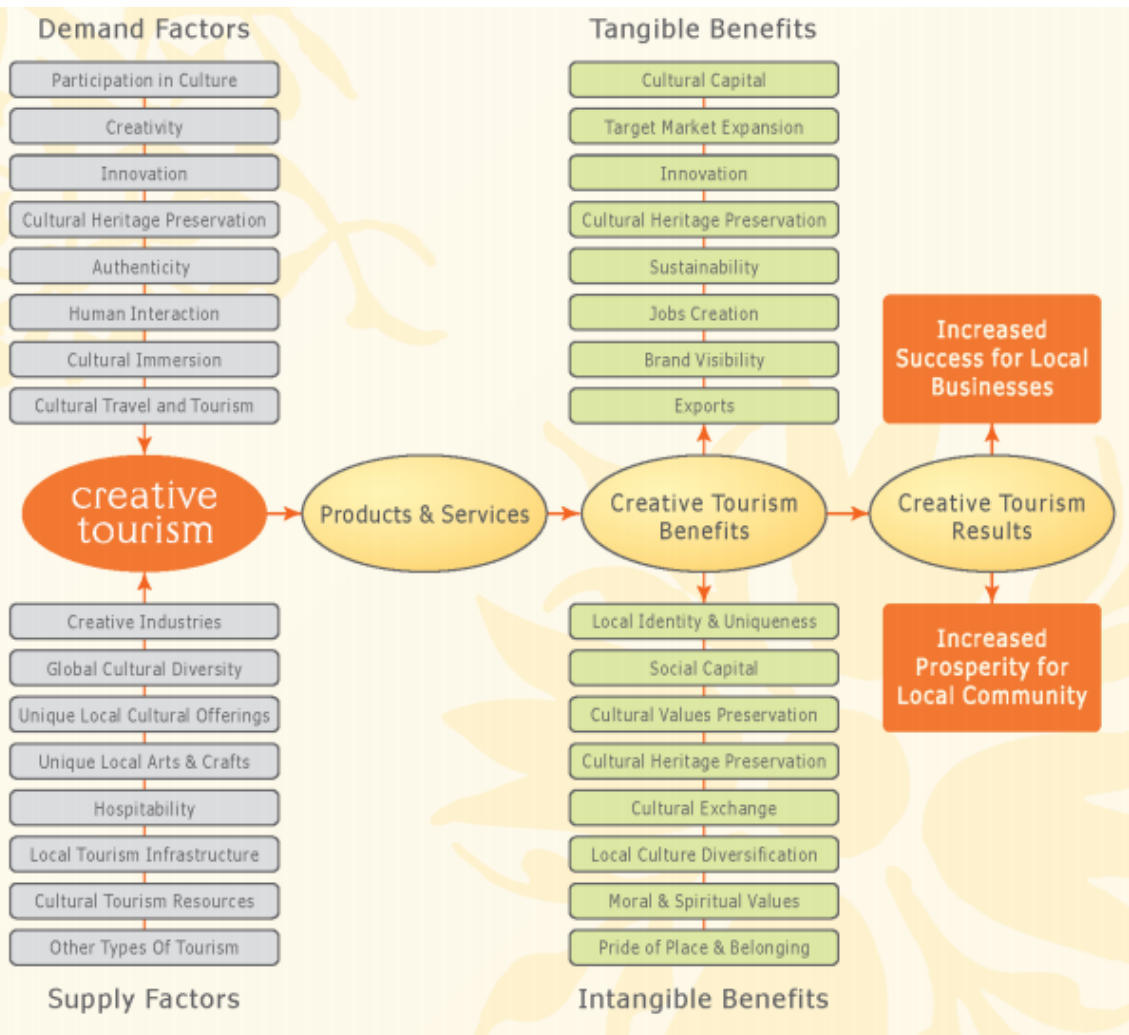

Fig. 14. Businnes model of creative tourism 
In the Fig. 14. is shown cretive tourism business model. The model has 5 elements: demand factors, supply factors, tangible benefits, intangible benefits and the finance results at the end. Following this model the supply side needs to involve all its factors and resources to create a unique tourism offer for creative tourist who are looking for the possibility to participate in the local culture. Demand side, the creative tourist are looking for way to express their creativity or to increase the creativity. The creative tourism is holding few tangible and intangible benefits which are shown in the Fig 14.

All mentioned traditional crafts and other culture elements in vernacular regions of Bosnia and Herzegovina should be involved in such model which would result with increased success for local businesses but also would result with increased prosperity for local community.

\section{CONCLUSION}

Based on terrain experience, the collected data and information, analysis of tourism potential, performed survey and regionalization, it is concluded that Bosnia and Herzegovina has a significant potential to develop creative tourism based on its heritage.

The wealth of Bosnia and Herzegovina lies in the diversity of its peoples, different customs, religious and cultural influences. Interactions of people created a mosaic of cultures and traditions. To be make a creative tourism out of culture and tourism it is necessary to develop a planned development strategy.

Vernacular of the region of Bosnia and Herzegovina in this paper shaped by the principle of a sense of belonging and the first association of the homeland. Mentioning a particular region, a person already has some knowledge or association of space, or "mental image" of the cultural identity of its people, historical events or economic activities.

All regions of Bosnia and Herzegovina have already been identified by a specific food product, traditional gastronomic specialty, the particular historical event, famous personalities or cultural - historical heritage. These are the region which gave rise to the potential for the development of creative tourism.

\section{Literature}

1. 1143-148.

2. Andaluz del Patrimonio Histórico. El Turismo Industrial y El Patrimonio Histórico De La Electricidad, pp. 170- 195.

3. APOSTOLAKIS, A., 2003. The Convergence Process in Heritage Tourism. Annals of Tourism Research, vol. 30, no. 4795-812.

4. BACHILLER, J.M., 1994. El Turismo Rural Como Propuesta De Revitalización Económica De Áreas Rurales

5. Becomes an Authentic Experience. Journal of Consumer Behaviour, Mar, vol. 7, no. 2111126.

6. BERNABÉU, A. and ROCAMORA, R., 2010. De "Span is Different" a "I Need Spain". La Función Apelativa En

7. CAMARERO, M.d.C. and GARRIDO, M.J., 2004. Marketing Del Patrimonio Cultural. Madrid: Pirámide.

8. Campañas Turísticas Españolas. Gran Tour: Revista De Investigaciones Turísticas, vol. 283-100. BRIASSOULIS, H., 2002. Sustainable Tourism and the Question of the Commons. Annals of Tourism Research, 10, vol. 29, no. 41065-1085. 
9. CAPEL, H., 1996. El turismo industrial y el patrimonio histórico de la electricidad. In: Catalogación del CASTRO LEÓN, J.F., 2005. La Calidad Como Herramienta De Gestión Del Turismo Cultural. Pasos, vol. 3, no.

10. CHRONIST, A. and HAMPTON, R.D., 2008. Consuming the Authentic Gettysburg: How a Tourist Landscape

11. CORTÉS, T., 2002. La Recuperación Del Patrimonio Urbano Como Recurso Turístico. Universidad Complutense de Madrid: .

12. DE ESTEBAN, J. and LÓPEZ, A., 2009. Una Aproximación Al Marketing Turístico Sostenible Desde La

13. DE ESTEBAN, J., 2007. La Demanda Del Turismo Cultural y Su Vinculación Con El Medio Ambiente Urbano: Los Casos De Madrid y Valencia. Madrid: Universidad Complutense de Madrid.

14. DE MIGUEL, M.d.M. and MIR, C., 2000. Gestión Tecnológica Del Patrimonio Turístico. Estudios Turísticos, vol. 14647-58.

15. Desfavorecidas: El Suroeste Soriana. Ería, vol. 3325-39.

16. GABLE, E. and HANDLER, R., 1996. After Authenticity at an American Heritage Site. American Anthropologist, 09, vol. 98, no. 3568.

17. Hanjalić A.,2014, Karakteristike i regionalizacija kulturnog turizma u Bosni i Hercegovini, rukopis, biblioteka Odsjeka za geografiju, PMF, Sarajevo,

18. JANSEN-VERBEKE, M., 1991. Leisure Shopping: A Magic Concept for the Tourism Industry?. Tourism Management, 3, vol. 12, no. 19-14.

19. MARTÍNEZ, F., 2004. El Potencial De La Actividad Turística Para Resolver De Manera Sostenible Los Problemas Estructurales De Las Zonas Rurales. Análisis Del Caso Gallego. Estudios Turísticos, vol. 15987-102.

20. Patrimonio Histórico. Actas de las I Jornadas sobre Catalogación del Patrimonio HistóricoSevilla: Instituto

21. Planificación Estratégica. Observatorio Medioambiental, vol. 1237-47.

Research, 4, vol. 30, no. 2386-405.

22. Richards G., Raymond, C. (2000) 'Creative tourism', ATLAS News, 23: 16-20

23. Richards, G. (2002) Creative tourism as a factor in destination development

24. Richards, G. and Wilson, J. (2007) The Creative Turn in Regeneration: Creative Spaces,

25. Sostenible Del Turismo Cultural. Cuadernos De Turismo, vol. 23237-253.Spectacles and Tourism in Cities

26. STRANGE, C. and KEMPA, M., 2003. Shades of Dark Tourism: Alcatraz and Robben Island. Annals of Tourism

27. VELASCO GONZÁLEZ, M., 2009. Gestión Turística Del Patrimonio Cultural: Enfoques Para Un Desarrollo 